\title{
Biotic or abiotic factors: which has greater influence in determining the structure of rotifers in semi-arid reservoirs?
}

Fatores bióticos ou abióticos: quais exibem maior influência na determinação da estrutura de rotíferos em reservatórios no semiárido?

Daniele Jovem da Silva Azevêdo ${ }^{1}$, José Etham de Lucena Barbosa² ${ }^{2}$ Danianne Enéias Porto ${ }^{3}$, Wilma Izabelly Ananias Gomes ${ }^{3}$ and Joseline Molozzi ${ }^{2}$

${ }^{1}$ Programa de Pós-graduaçáo em Ecologia e Conservação, Universidade Estadual da Paraíba - UEPB, Campus I, Rua Baraúnas, 351, Bairro Universitário, CEP 58429-500, Campina Grande, PB, Brazil e-mail: daniele.jazevedo@gmail.com

${ }^{2}$ Departamento de Biologia, Universidade Estadual da Paraíba - UEPB, Campus I, Rua Baraúnas, 351, Bairro Universitário, CEP 58429-500, Campina Grande, PB, Brazil e-mail: ethambarbosa@hotmail.com; jmolozzi@gmail.com

${ }^{3}$ Graduação em Ciências Biológicas, Universidade Estadual da Paraíba - UEPB, Campus I, Rua Baraúnas, 351, Bairro Universitário, CEP 58429-500, Campina Grande, PB, Brazil e-mail: daianneporto@yahoo.com.br; wilmaizabelly@hotmail.com

\begin{abstract}
Objective: The objective of this study is to evaluate whether the distribution of structural attributes of rotifers in reservoirs in the semiarid region is more strongly influenced by abiotic or biotic environmental factors (density of cyanobacteria). Method: Sampling occurred in two reservoirs in the Paraíba Basin, northeastern Brazil (Poçôes and Camalaú) during April and June 2012. Eight sampling points were distributed at two stations in each reservoir: the region near the entrance of the main tributary and region of the dam and collections were made in the limnetic and littoral zone in every season. To assess the abiotic influence and density of cyanobacteria in the distribution of the structural attributes of rotifers, environmental variables bivariate correlation was conducted in series. Results: In Poções reservoir, the distribution of rotifer biomass was negatively related to the density of cyanobacteria; among the environmental variables, chlorophyll-a and total nitrogen were negatively related to all of the tested structural attributes, while the concentrations of total phosphorus were strongly related to the abundance of rotifers. In the Camalaú reservoir, the biomass was a structural attribute with a stronger correlation to the density of cyanobacteria; between the environmental variables and Egeria densa, nitrate was negatively related to all of the attributes tested, while transparency was moderately related to the abundance, biomass and richness as well as Chara sp. with abundance. Conclusions: Assemblages of rotifers are more clearly related to environmental conditions, especially those indicative of trophic conditions, despite the density of cyanobacteria having been a factor that was positively related to the structural characteristics of rotifers and thus indicative of such structural assemblies. This can be used for analysis of local environmental condition factors.
\end{abstract}

Keywords: cyanobacteria; environmental factors; zooplankton; reservoir.

Resumo: Objetivo: $\mathrm{O}$ objetivo deste trabalho é avaliar se a distribuição dos atributos estruturais de rotíferos em reservatórios no semiárido é mais fortemente influenciada por determinantes ambientais abióticos ou bióticos (densidade de cianobactérias). Método: As amostragens ocorreram em dois reservatórios na Bacia do Rio Paraíba, nordeste do Brasil (Poçôes e Camalaú) durante abril e junho de 2012. Oito pontos de amostragem foram distribuídos em duas estações em cada reservatório: região próxima a entrada do principal tributário e regiáo de barragem e em cada estação foram realizadas coletas na zona litorânea e limnética. Para avaliação da influência das variáveis ambientais abióticas e da densidade de cianobactérias na distribuiçâo dos atributos estruturais de rotíferos foi realizada análise de série bivariada de correlação. Resultados: No reservatório Poçóes, a distribuição da biomassa de rotíferos esteve negativamente relacionada com a densidade de cianobactérias e entre as variáveis ambientais a clorofila- $a$ e nitrogênio total foram negativamente relacionadas com todos os atributos estruturais testados enquanto que as 
concentraçôes de fósforo total estiveram fortemente relacionadas com a abundância dos rotíferos. No reservatório Camalaú, a biomassa foi o atributo estrutural com maior fator de correlação com a densidade de cianobactérias e dentre as variáveis ambientais, Egeria densa e nitrato foram relacionadas negativamente com todos os atributos testados, enquanto que a transparência esteve moderadamente relacionada com a abundância, biomassa e riqueza, assim como Chara sp. esteve com a abundância. Conclusóes: As assembleias de rotíferos é mais claramente relacionada a condiçóes ambientais, especialmente as indicativas de condiçôes tróficas, apesar da densidade de cianobactéria ter sido um fator que esteve positivamente relacionado com os atributos estruturais dos rotíferos e desta forma os indicativos estruturais dessas assembleias podem ser utilizados até mesmo como fatores de análise das condiçôes ambientais locais.

Palavras-chave: cianobactérias; fatores ambientais; zooplâncton; reservatórios.

\section{Introduction}

Rivers and their watersheds are constantly under anthropogenic influence (Duffy et al., 2007), which has driven ecologists in the development of studies that assess the functioning of ecosystems subjected to different levels of impacts (Moreno et al., 2009; Tixier et al., 2011). Understanding the anthropogenic factors that affect the distribution of species as well as the structural attributes of communities are key elements in understanding the cause-effect that leads to reduction of local biodiversity, especially in freshwater bodies, which should also help to propose management measures regarding the threats at regional and local scales (Bunn \& Arthington, 2002; Badsi et al., 2010).

Reservoirs are products of changes in hydromorphological patterns, constructed from the impoundment of the natural flow of a river, converting lotic into lentic systems (Fanny et al., 2013). Although artificial, reservoirs form a network of different elements in the landscape that contribute to local biodiversity conservation, being considered important sites for refuges of species richness (Tundisi, 1999; Brainwood \& Burgin, 2009; Chester \& Robson, 2013).

The construction of reservoirs in semiarid regions is frequent and extremely important, because they allow the retention of water in order to meet the needs of human populations during drought, and the development of irrigation, fish farming, and industrial and leisure activities (Annor et al., 2009; Chellappa et al., 2009). The multiple uses of these water bodies combined with anthropogenic impacts on watershed, as well as the lack of management plans, has favored the artificial eutrophication which has led to a loss of water quality and biodiversity (Revenga et al., 2005; Serediak et al., 2014).

Zooplankton is an important tool for assessing the trophic status of water bodies because the community structure has been related to the water chemistry and anthropogenic pressures on these ecosystems (An et al., 2012). Some authors have used changes in zooplankton communities to monitor processes regarding the restoration of aquatic environments (Benndorf, 1995; Zhao et al., 2008; Peretyatko et al., 2009).

Rotifers are a group of zooplankton with large species richness and show important participation as a link in the transfer of energy to higher trophic levels and in the cycling of matter (Wen et al., 2011). In addition, these organisms are sensitive to environmental alterations, considering the rapid fluctuation of biological characters, and are therefore considered good indicators of the quality of water bodies (An et al., 2012; Malekzadeh Viayeh \& Spoljar, 2012).

Abiotic and biotic factors are reported as drivers of abundance, biomass and richness of rotifer populations (Bielańska-Grajner \& Gładysz, 2010; Chen et al., 2011). Among the abiotic variables, transparency, depth, temperature, $\mathrm{pH}$, nitrogen and phosphorus have been reported as the most important for the distribution of structural attributes of the population (Wang et al., 2010).

Besides these factors, the presence of macrophytes has long been reported as a director to the structure of the species, because it contributes to the formation of areas with a higher degree of heterogeneity, availability of micro-habitats and effective niches, allowing the coexistence of species, and decreasing the sharing of resources and subsequent competition (Pianka, 1988; Bell et al., 1991; Downes et al., 2000; Taniguchi et al., 2003; Burlakova et al., 2012). Considering biotic factors, predation, competition and the availability of food resources are reported to be the most important (Arora \& Mehra, 2003; Wen et al., 2011).

Another biotic factor that is often listed is the relationship between rotifers and cyanobacteria. Geng et al. (2005) emphasized that analysis of the rotifer structure versus the cyanobacteria population 
enabled the changes and effects of eutrophication on the functioning of aquatic ecosystems to be related.

In freshwater bodies, cyanobacteria blooms are frequently observed, especially those formed by Cylindrospermopsis raciborskii (Woloszynska) Seenaya \& Subba Raju (1972), Microcystis aeruginosa (Kützing) Kützing (1846) or Planktothrix agardhii (Gomont) Anagnostidis \& Komárek (1888) (McGregor \& Fabbro, 2000; Moura et al., 2007; Dantas et al., 2008; Kokociński et al., 2010; Bonilla et al., 2012). Especially in reservoirs, the high proliferation rates of these organisms occur due to favorable characteristics of reservoirs: high temperatures, high concentrations of nutrients especially nitrogen and phosphorus, alkaline $\mathrm{pH}$, long residence time of water (on average 3-5 years) (Moura et al., 2011; Vasconcelos et al., 2011).

The dominance of cyanobacteria and the occurrence of blooms cause changes in the trophic levels and adverse impacts on the functioning of ecosystems (Vasconcelos et al., 2013). Some species of cyanobacteria produce allelopathic substances that prevent the growth of submerged vegetation and other algae, as well as increased resistance to predation by zooplankton, reducing the diversity of grazing species (e.g. rotifers) (Scheffer et al., 1993; Havens, 2008).

Rotifers assume a role as a link in the energy transfer in aquatic ecosystems, and, for this reason, the changes that occur in the community of the primary producers can reflect the structural attributes of the zooplankton community (EskinaziSant'Anna et al., 2007). In this way, the changes undergone by these water bodies, such as those arising from the eutrophication process, can be evaluated through the relationship between herbivorous zooplankton (rotifers) versus densities of cyanobacteria, in addition to physical and chemical factors of the water (Eskinazi-Sant'Anna et al., 2013).
Given the above, the main goal of this study was to evaluate whether the distribution of structure attributes of rotifers in semi-arid reservoirs is more strongly influenced by abiotic or biotic environmental determinants (density of Cyanobacteria). For this, we tested the hypothesis that structural attributes of rotifers are more strongly related to abiotic determinants, especially nitrogen and phosphorus, and that high densities of cyanobacteria are negatively related to the richness, considering that rotifer richness is restricted to those species with a tolerance to coexist with high densities of these organisms.

\section{Material and Methods}

\subsection{Study area}

The samplings were collected in two reservoirs, Poçôes and Camalaú, of the Paraíba River basin, northeastern Brazil (6 $0^{\circ} 51^{\prime} 31^{\prime \prime} ; 8^{\circ} 26^{\prime} 21^{\prime \prime} \mathrm{S}$ and $\left.34^{\circ} 48^{\prime} 35^{\prime \prime} ; 37^{\circ} 2^{\prime} 15^{\prime \prime} \mathrm{W}\right)$ for study (Figure 1). The Paraíba River is part of transposition of the São Francisco River, and the Poçóes and Camalaú reservoirs are receptor ecosystems of waters in the northern axis of the transposition. The climate is semi-arid dry, low latitude and altitude (BSh), according to Köppen-Geiger (Köppen, 1936), with average rainfall of $400 \mathrm{~mm} /$ year and minimum air temperature ranging from $18-22^{\circ} \mathrm{C}$ (July and August), with a maximum of $28-31^{\circ} \mathrm{C}$ (November and December) (AESA, 2010).

The characterization data of the Poçóes and Camalaú reservoirs are shown in Table 1.

\subsection{Sampling sites, periods and water volume}

In each reservoir, eight sampling sites were distributed in two regions: 1 ) four in the region near the inflow of the main tributary (Paraíba River) and 2) four in the region near the dam; for every region, collections were performed between the littoral and limnetic zones. In the littoral zone, samplings were

Table 1. Characterization of Poções and Camalaú reservoirs, Paraíba River basin, State of Paraíba, northeastern Brazil. Source: Executive Agency of Water Management of the State of Paraíba (AESA, 2010).

\begin{tabular}{lcc}
\hline \multicolumn{1}{c}{ Characteristics } & Poções Reservoir & Camalaú Reservoir \\
\hline Geographic Location & $7^{\circ} 53^{\prime} 38^{\prime \prime} \mathrm{S}-37^{\circ} 0^{\prime} 30^{\prime \prime} \mathrm{W}$ & $7^{\circ} 53^{\prime} 33.94^{\prime \prime} \mathrm{S}-36^{\circ} 50^{\prime} 39.16^{\prime \prime} \mathrm{W}$ \\
Year of Construction & 1982 & ${ }^{*}$ \\
Altitude $(\mathrm{m})$ & 596 & 565 \\
Maximum accumulation capacity $\left(\mathrm{m}^{3}\right)$ & $29,861,562$ & $48,107,240$ \\
Water surface $\left(\mathrm{m}^{2}\right)$ & $19,005,95$ & $19,457,18$ \\
Hydraulic retention time (years) & $3-5$ & $3-5$ \\
Presence of macrophytes & - & Egeria densa and Chara sp \\
\hline
\end{tabular}

*non-reported data. 


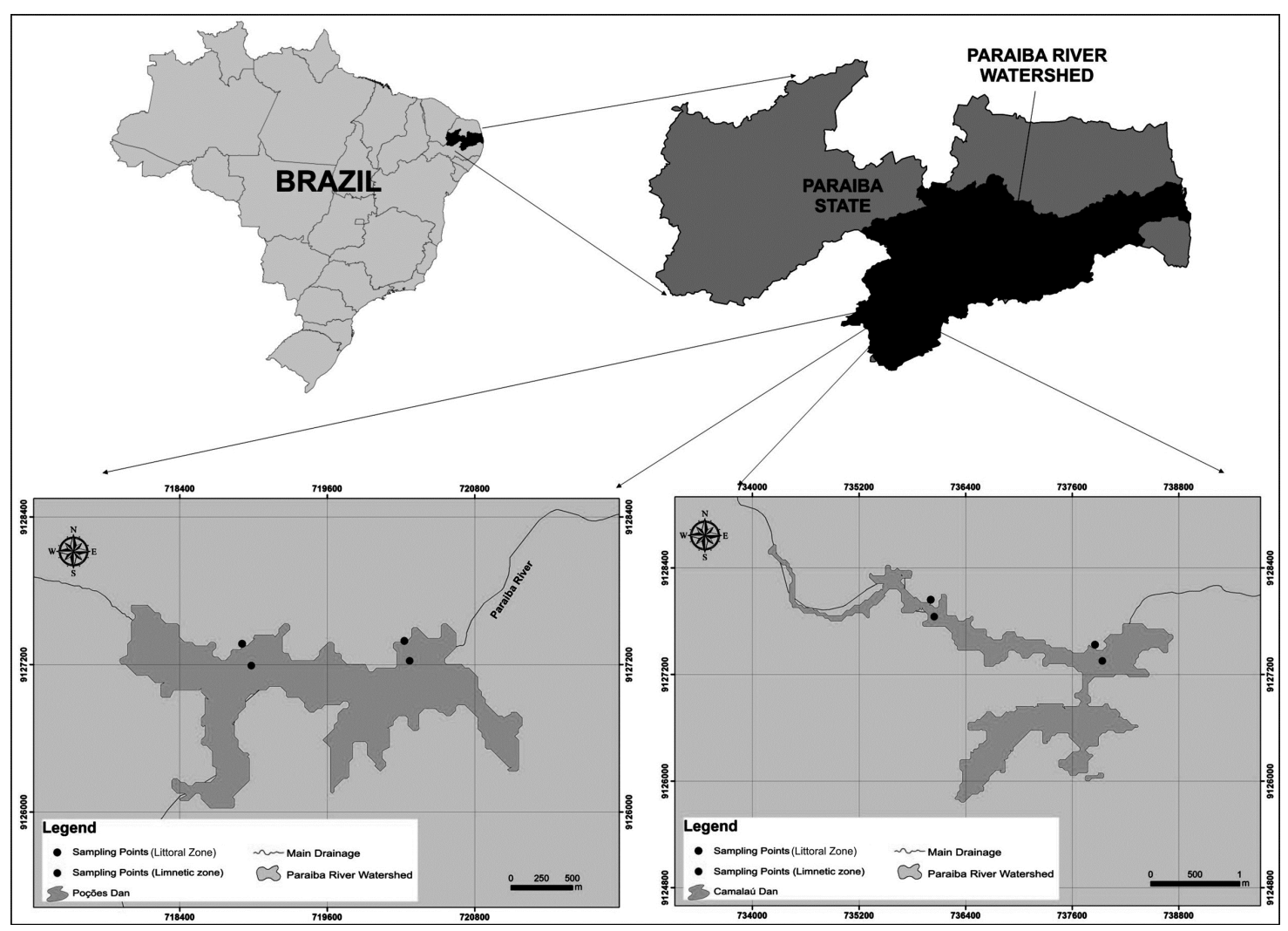

Figure 1. Location of Poções and Camalaú reservoirs, Paraíba River basin, State of Paraíba, Brazil.

performed under the water surface $( \pm 30 \mathrm{~cm}$ from the water surface), and in the limnetic zone, three depths were established along the water column: sub-surface, $1 \%$ light incidence and aphotic zone.

Sampling occurred in April and June 2012. The larger volume of water in reservoirs occurred in April, with the record of 12,657,210 $\mathrm{m}^{3}$ in the Poções Reservoir (42.4\% maximum capacity) and $23,894,517 \mathrm{~m}^{3}$ in the Camalaú Reservoir (49.7\% maximum capacity). During the sampling period in June, the volumes were $11,092,275 \mathrm{~m}^{3}$ for the Poçóes Reservoir (37.2\% maximum) and $22,123,615 \mathrm{~m}^{3}$ for the Camalaú Reservoir $(46 \%$ maximum) (AESA, 2013).

\subsection{Environmental variables}

At each sampling site, the following variables were measured: temperature $\left({ }^{\circ} \mathrm{C}\right), \mathrm{pH}$, electrical conductivity $\left(\mu \mathrm{S} / \mathrm{cm}^{-1}\right)$, turbidity (NTU), dissolved oxygen $\left(\mathrm{mg} / \mathrm{L}^{-1}\right)$, oxidation-reduction potential and salinity $(\mathrm{ppm})$, using a multi-analyzer probe (Horiba/U-50). Water transparency was estimated by the disappearance of the Secchi disk and the euphotic zone according to Cole (1994). For chemical analysis, one liter of water was collected with a van Dorn bottle and used in the laboratory to determine concentrations of total phosphorus $\left(\mu \mathrm{g} / \mathrm{L}^{-1}\right)$, soluble reactive phosphate $\left(\mu \mathrm{g} / \mathrm{L}^{-1}\right)$, total nitrogen $\left(\mu \mathrm{g} / \mathrm{L}^{-1}\right)$, ammonium ions $\left(\mu \mathrm{g} / \mathrm{L}^{-1}\right)$, nitrate $\left(\mu \mathrm{g} / \mathrm{L}^{-1}\right)$ and nitrite $\left(\mu \mathrm{g} / \mathrm{L}^{-1}\right)$, according to Standard Methods for the Examination of Water and Wastewater (APHA et al., 1992). The concentration of chlorophyll-a $\left(\mu \mathrm{g} / \mathrm{L}^{-1}\right)$ was estimated by $90 \%$ acetone extraction (Lorenzen, 1967).

In the reservoir in which macrophytes were observed, individuals were collected with the aid of a collector hook $\left(0.62 \mathrm{~m}^{2}\right)$ in the littoral zone and fixed with 10\% formalin (Medina-Gomez \& HerreraSilveira, 2006). The specimens were identified and subsequently placed in an oven at $105^{\circ} \mathrm{C}$ to obtain the dry weight. The biomass estimate was performed according to the methodology described by Blindow et al. (2006). This variable was assessed to relate their co-relationship as a director for the structure of rotifers.

\subsubsection{Biotic variable}

\subsubsection{Cyanobacteria}

Qualitative samples were obtained from the filtration of water with a $20 \mu \mathrm{m}$ plankton net, which were subsequently placed in plastic bottles and fixed with Transeau solution. Quantitative samples were collected with a Van Dorn bottle and fixed with acetic 
Lugol. In the laboratory, individuals were identified to the species level when possible, based on specific literature (Anagnostidis \& Komárek, 1988; Bicudo \& Menezes, 2006; Komárek \& Anagnostidis, 1989; Sant'Anna et al., 2006). Counting of cyanobacteria taxa was carried out by sedimentation (Utermöhl, 1958), using an inverted microscope (Zeiss/ Axiorvert) at $400 \mathrm{X}$ magnification. The settling time was at least three hours for each centimeter of chamber height (Margalef, 1981). Individuals (cells, colonies, filaments) were counted in random fields (Uhelinger, 1964) in a sufficient number to achieve 400 individuals of the most common species, with an error less than 5\% ( $<$ < 0.05) (Lund et al., 1958). The number of individuals per unit volume was calculated according to Ross (1979).

\subsubsection{Rotifers}

Quantitative samples were obtained from the filtration (through a plankton net with a mesh size of $68 \mu \mathrm{m}$ ) of a volume corresponding to $100 \mathrm{~L}$ water at all sampling sites; aliquots were fixed in glycosylated $4 \%$ formaldehyde. Individuals were identified to the lowest taxonomic level possible (Ruttner-Kolisko, 1974; Koste, 1978) and counted in a SedgewickRafter chamber (1 mL capacity) until the coefficient of variation of the most abundant species was less than $5 \%$.

Biomass was estimated from the biovolume of the most abundant species, in which 30 individuals were randomly chosen and measured, using approximate geometric forms (Ruttner-Kolisko, 1977; Pinto-Coelho, 2004). The wet weight was estimated from biovolume assuming that $106 \mu \mathrm{m}^{3}$ corresponds to $1 \mu \mathrm{g}$ wet weight, and dry weight was estimated as $10 \%$ of the wet weight (Pace $\&$ Orcutt, 1981).

\subsubsection{Data analysis}

Richness was represented by the absence and presence of different species in each sampling site. A Permutational Multivariate Analysis of Variance (PERMANOVA) (Anderson, 2001a, b; Anderson \& Ter Braak, 2003, Anderson et al., 2008) was applied to detect significant variations in the distribution patterns of the structural attributes (richness, abundance, diversity and biomass) of rotifer species and environmental variables between zones (littoral and limnetic), reservoirs and sampling periods. Three fixed factors were selected: zone (two levels: littoral and limnetic); reservoir (two levels: Poçôes and Camalaú) and sampling period (two levels: high water volume of the reservoir and lower water volume). Significant terms were investigated using tests with 999 permutations and a significance level chosen a priori of $\alpha \leq 0.05$. Environmental data were previously transformed into $\log _{x+1}$ and data of abundance and biomass into square root; for richness, the Jaccard index (presence/absence of species) was used. The Bray Curtis similarity index was employed for the structural aspects tested.

In order to evaluate the influence of abiotic variables and density of cyanobacteria on the distribution of structure attributes of rotifers, a series of bivariate correlation analysis (Draftsman's Plot) was run. This analysis calculated the correlation coefficient between pairs of variables, providing an estimate of interpolation between variables (Clarke \& Ainsworth, 1993). Environmental variables were selected beforehand and, for this, a Spearman correlation analysis was run between the structure attributes of rotifers with the variables measured; those variables that were significantly related ( $p \leq 0.05$ ) were selected to compose the Draftsman's plot.

\section{Results}

\subsection{Environmental variables}

The highest value of the average water temperature was in the Camalaú Reservoir $\left(27.13 \pm 1.35^{\circ} \mathrm{C}\right)$ in the littoral zone during the period of high water volume. Besides high temperatures, the $\mathrm{pH}$ of the waters in the reservoirs indicated basic conditions (range 8-9). The concentration of total phosphorus was different for both reservoirs; the highest values were observed in the Poçôes Reservoir in the limnetic zone in the period of the high water level (273.27 $\left.\mu \mathrm{g} \mathrm{L}^{-1} \pm 2.66\right)$. The highest values of total nitrogen were also found in the Poções Reservoir, in the high water volume, but in the littoral zone (1585.53 $\left.\mu \mathrm{g} \mathrm{L}^{-1} \pm 190.51\right)$. The highest values of chlorophyll-a were registered in the Poçôes Reservoir $\left(128.23 \mu \mathrm{gL}^{-1} \pm 19.86\right)$ in the limnetic zone in the high water volume, whereas lower concentrations were verified $\left(10.89 \mu \mathrm{gL}^{-1} \pm 1.39\right)$ in the Camalaú Reservoir. Mean values and standard variation of all environmental variables measured are listed in Table 2.

Significant differences were found between zones (Pseudo- $\mathrm{F}_{1,31}=9.072 ; \mathrm{p}=0.001$ ), reservoirs (Pseudo- $\mathrm{F}_{1,31}=19.419 ; \mathrm{p}=0.001$ ) and sampling periods (Pseudo- $\mathrm{F}_{1,31}=3.518 ; \mathrm{p}=0.001$ ).

\subsection{Structural aspects of Rotifers}

A total of 13 rotifer taxa were identified during the study period for both reservoirs; the highest 


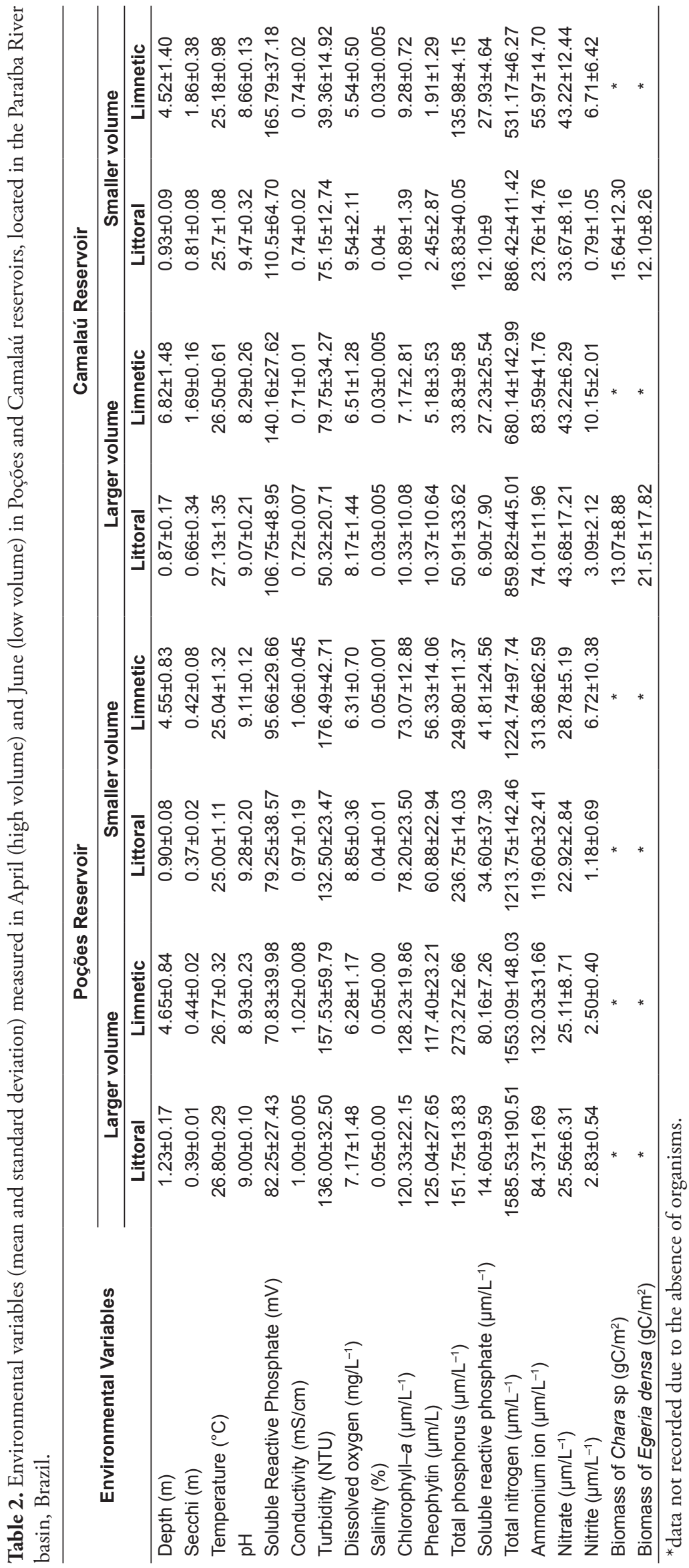


richness was observed in the Camalaú Reservoir (9 taxa) in the limnetic zone during the period of low water level. Among the identified taxa, Brachionus havanaensis Rousselet (1911) and Filinia opolienses Ehrenberg (1834) were the most representative, for both abundance and biomass. In the Poçôes Reservoir, the numeric abundance of Brachionus havanaensis accounted for $31.94 \%$ (10.220 individuals) of the total individuals collected, while Filinia opolienses had 16.91\% representativeness (5.411 individuals) in the rotifer community. As for biomass, Brachionus havanaensis represented $23.53 \%\left(316.02\right.$ DW.m $\left.^{-3}\right)$ and Filinia opoliensis $13.01 \%\left(174.77 \mathrm{DW} \cdot \mathrm{m}^{-3}\right)$ of the total biomass of the rotifer community. Higher values of abundance and biomass in the Poçóes Reservoirs were observed in the limnetic zone in the high water level (Table 2).

In the Camalaú Reservoir, the greater representativeness of abundance and biomass was found for Filinea opolienses, with $48.05 \%$ (1.838 individuals) and $30.36 \%$ (27.17 DW.m $\left.{ }^{-3}\right)$, respectively. In turn, Brachionus havanaensis represented $17.35 \%$ (664 individuals) of the total abundance and $18.07 \%$ (16.17 DW.m ${ }^{-3}$ ) of the total biomass. In this reservoir, the maximum abundance and biomass were recorded in the limnetic zone during the period of low water volume (Table 2).

Significant differences were reported for the distribution of rotifer abundance between littoral and limnetic zones (Pseudo- $\mathrm{F}_{1,31}=3.771$; $\mathrm{p}=0.005$ ), reservoirs (Pseudo- $\mathrm{F}_{1,31}=23.593$; $\mathrm{p}=0.001)$ and sampling periods of high and low volume of water (Pseudo- $F_{1,31}=3.4272 ; \mathrm{p}=0.022$ ). For biomass, significant differences were found between zones (Pseudo- $\mathrm{F}_{1,31}=3.555 ; \mathrm{p}=0.013$ ), reservoirs (Pseudo- $\mathrm{F}_{1,31}=26.619 ; \mathrm{p}=0.001$ ) and sampling periods (Pseudo- $\mathrm{F}_{1,31}=3.941 ; \mathrm{p}=0.007$ ). Significant differences in richness were found between zones (Pseudo- $\mathrm{F}_{1,31}=16.174 ; \mathrm{p}=0.001$ ), reservoirs (Pseudo- $\mathrm{F}_{1,31}=29.826 ; \mathrm{p}=0.001$ ) and sampling periods (Pseudo- $\mathrm{F}_{1,31}=17.87 ; \mathrm{p}=0.001$ ). (Table 3).

\subsection{Density of cyanobacteria}

During the study period, 29 taxa were identified for both reservoirs, with the highest richness recorded for the Poçóes Reservoir (29 taxa) (Table 4). The maximum values of total density of cyanobacteria were observed in the limnetic zone during the period of low water level in both reservoirs (Poções - 7,855.64 ind. $\mathrm{mL}^{-1}$, Camalaú 804.52 ind. $\mathrm{mL}^{-1}$ ) (Table 4).

In the Poções Reservoir, Cylindrospermopsis raciborskii was the most representative taxon (69\%) for the total density of cyanobacteria, followed by Planktothrix agardhii (14.04\%) and Geitlerinema sp. (10.36\%). In the Camalaú Reservoir, the density of cyanobacteria was considerably lower than the density values registered in the Poçóes Reservoir, and Coelomoron sp. was the most representative (24.84\%) for the total density, followed by Cylindrospermopsis raciborskii (16.25\%) and Planktothrix agardhii (15.17\%).

Significant differences were detected in the density of cyanobacteria between littoral and limnetic zones (PERMANOVA: Pseudo-F ${ }_{1,61}=4.248 ; \mathrm{p}=0.005$ ), reservoirs (PERMANOVA: Pseudo- $F_{1,61}=39.265$; $\mathrm{p}=0.001)$ and periods of high and low water level (PERMANOVA: Pseudo-F ${ }_{1,61}=6.318 ; \mathrm{p}=0.001$ ) (Table 5).

\subsection{Relationship between rotifers and abiotic and biotic determinants}

Analyzing the structure attributes of rotifers in relation to the density of cyanobacteria by means of the correlation analysis (Draftsman's plot), the density of cyanobacteria was weakly related to the structural attributes throughout the study period, as shown in Figures 2 and 3. In the Poçóes Reservoir, the distribution of rotifer biomass was negatively related to the density of cyanobacteria (Figure 2). In contrast, the biomass in the Camalaú Reservoir was the attributed to the highest correlation, which enabled the observation that the lowest values of biomass rotifers were related to the mean values of the density of cyanobacteria (Figure 3).

Considering the environmental variables, there were differences for those significantly related to the distribution of structure attributes between Poções and Camalaú reservoirs. In Poçóes, chlorophyll-a and total nitrogen were negatively related to all of the structure attributes tested; concentrations of total phosphorus were strongly related to the abundance and moderately related to biomass and richness. In the Camalaú Reservoir, Egeria densa and nitrate were negatively related to all of the attributes tested, while transparency was moderately related to the abundance, biomass and richness, and Chara sp. was related to the abundance of rotifers. The spatial distribution of structural attributes related to the biotic and abiotic variables can be seen in Figures 4 and 5 . 


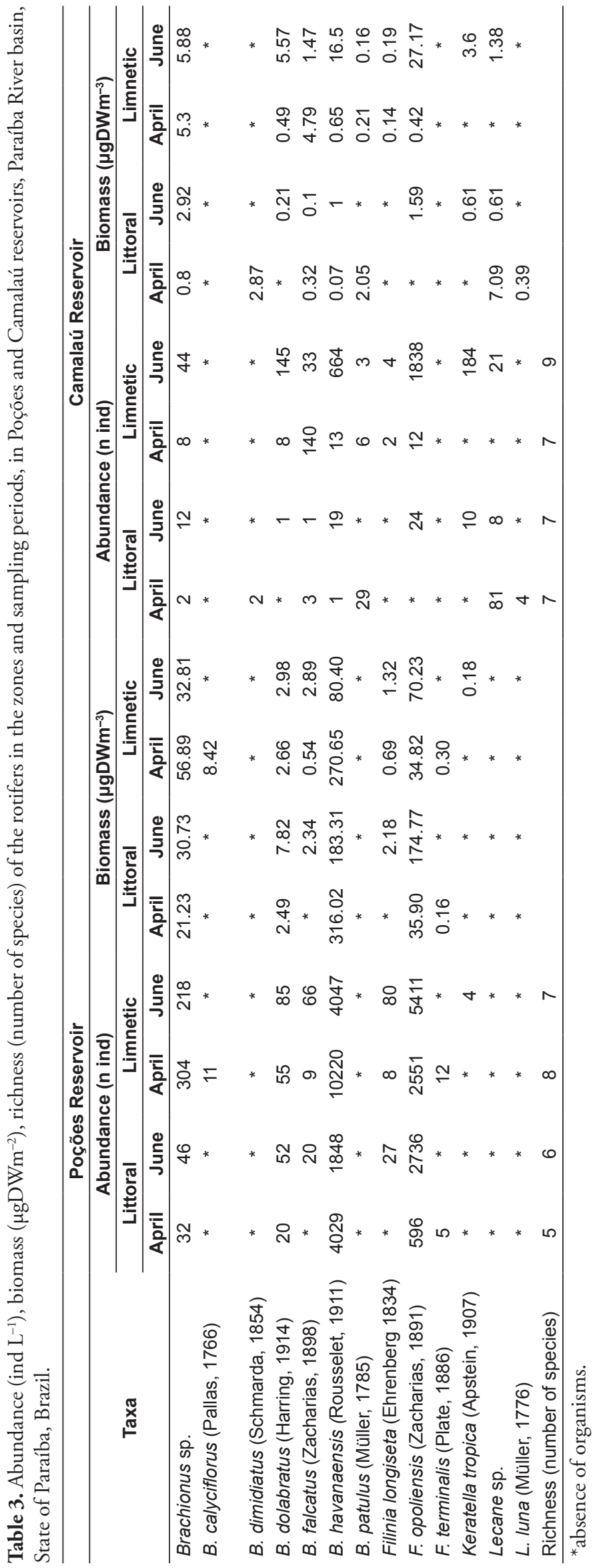


Table 4. Taxa of the Cyanobacteria community. Values of density (individuals/L) in the zones and sampling periods, in Poções and Camalaú reservoirs, Paraíba River basin, State of Paraíba, Brazil.

\begin{tabular}{|c|c|c|c|c|c|c|c|c|}
\hline \multirow{4}{*}{ Taxa } & \multicolumn{4}{|c|}{ Poções Reservoir } & \multicolumn{4}{|c|}{ Camalaú Reservoir } \\
\hline & \multicolumn{4}{|c|}{ Density (ind/L) } & \multicolumn{4}{|c|}{ Density (ind/L) } \\
\hline & \multicolumn{2}{|c|}{ Littoral } & \multicolumn{2}{|c|}{ Limnetic } & \multicolumn{2}{|c|}{ Littoral } & \multicolumn{2}{|c|}{ Limnetic } \\
\hline & $\begin{array}{l}\text { Larger } \\
\text { volume }\end{array}$ & $\begin{array}{l}\text { Smaller } \\
\text { volume }\end{array}$ & $\begin{array}{l}\text { Larger } \\
\text { volume }\end{array}$ & $\begin{array}{l}\text { Smaller } \\
\text { volume }\end{array}$ & $\begin{array}{l}\text { Larger } \\
\text { volume }\end{array}$ & $\begin{array}{l}\text { Smaller } \\
\text { volume }\end{array}$ & $\begin{array}{l}\text { Larger } \\
\text { volume }\end{array}$ & $\begin{array}{l}\text { Smaller } \\
\text { volume }\end{array}$ \\
\hline Aphanizomenon sp & * & 42.37 & 2.01 & 106.93 & * & * & * & * \\
\hline A. delicatissima & * & * & 23.20 & 18.15 & 7.06 & 8.07 & * & 13.11 \\
\hline Aphanocapsa sp & * & * & 2.01 & 9.07 & 14.62 & * & 46.90 & 46.90 \\
\hline Aphanotece sp & 38.83 & * & 15.63 & * & * & * & * & * \\
\hline Chrococcus sp & 12.10 & 5.04 & 61.53 & 3.02 & 1.51 & 7.06 & * & 21.68 \\
\hline Coelomorom sp & 4.53 & 3.02 & 23.20 & 27.23 & 89.28 & 23.70 & 147.79 & 213.36 \\
\hline Coelomoron tropicale & * & 14.12 & 2.01 & 27.23 & * & * & * & * \\
\hline Coelosphaerium sp & 14.12 & 5.04 & 6.55 & 10.08 & 1.51 & 4.03 & 32.78 & 81.71 \\
\hline Cylindrospermopsis raciborskii & 792.42 & 1848.14 & 2800.47 & 5725.02 & 39.84 & 60.02 & 120.04 & 90.28 \\
\hline Dolycospermum sp & 1.00 & * & * & 31.27 & 2.01 & 17.65 & * & 0.50 \\
\hline Geitlerinema sp & 334.92 & 30.26 & 1140.46 & 166.45 & 34.29 & 53.97 & * & 16.64 \\
\hline Leptolyngbya sp & * & 1.00 & * & * & 12.10 & 8.07 & 7.06 & 34.29 \\
\hline Limnococcus sp & * & * & * & 6.05 & * & * & * & * \\
\hline Limnotrix planctonica & * & * & * & 2.01 & * & * & 1.00 & * \\
\hline Limnotrix sp & * & 13.10 & * & * & 0.50 & 1.51 & * & * \\
\hline Lyngbya plantonica & * & * & * & * & * & 7.56 & 52.96 & 116.51 \\
\hline Lyngbya sp & * & * & * & * & 9.07 & 61.03 & * & 26.73 \\
\hline Merismopedia mínima & 3.53 & 35.30 & 82.21 & 157.37 & 1.00 & 6.55 & 0.50 & 0.50 \\
\hline Merismopedia punctata & 1.00 & 14.12 & 5.04 & 4.03 & * & * & * & * \\
\hline Microcystis panniformis & * & * & * & 4.03 & 6.55 & * & 1.51 & 1.51 \\
\hline Microcystis proctocystis & 9.07 & * & 10.08 & * & 3.53 & 11.09 & 2.01 & * \\
\hline Oscilatoria sp & * & * & * & 2.01 & * & * & * & * \\
\hline Planktothrix agardhii & 141.23 & 331.90 & 335.43 & 1457.73 & 28.75 & 53.46 & 90.79 & 116.51 \\
\hline Planktothrix isotrix & * & 13.11 & * & 104.91 & 6.05 & 3.02 & 14.12 & 23.20 \\
\hline Pseudanabaena galeata & * & 1.51 & * & 4.03 & * & * & * & * \\
\hline Radiocystis sp & $1.00^{*}$ & * & * & * & * & * & * & * \\
\hline Sphaerocavum brasiliensi & 2.01 & 9.07 & 22.19 & 13.11 & * & 1.00 & 0.50 & 1.00 \\
\hline Thiconema sp & * & * & * & 1.00 & * & * & * & * \\
\hline
\end{tabular}

*absence of organisms.

Table 5. Results of PERMANOVA for the structural aspects of the rotifers, density of Cyanobacteria and environmental variables in different zones, reservoirs and sampling period.

\begin{tabular}{|c|c|c|c|c|c|c|c|c|c|}
\hline \multicolumn{10}{|c|}{ Rotifer } \\
\hline \multirow{2}{*}{ Factors } & \multicolumn{3}{|c|}{ Abundance } & \multicolumn{3}{|c|}{ Biomass } & \multicolumn{3}{|c|}{ Richness } \\
\hline & df & Pseudo-F & $P($ perm) & df & Pseudo-F & $\mathrm{P}$ (perm) & df & Pseudo-F & $P($ perm $)$ \\
\hline Zones & 1 & 3.771 & 0.005 & 1 & 3.555 & 0.013 & 1 & 16,174 & 0,001 \\
\hline Reservoirs & 1 & 23.593 & 0.001 & 1 & 26.619 & 0.001 & 1 & 29,826 & 0,001 \\
\hline Sampling period & 1 & 3.4272 & 0.022 & 1 & 3.941 & 0.007 & 1 & 17,87 & 0,001 \\
\hline Total & 31 & & & & & & & & \\
\hline
\end{tabular}

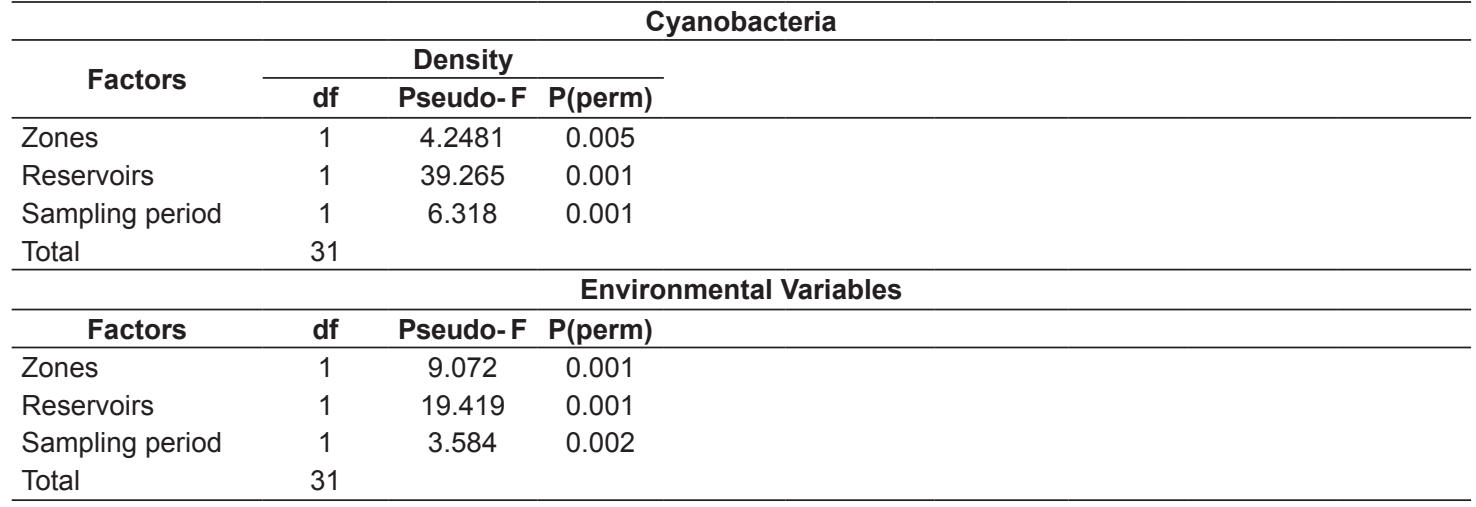



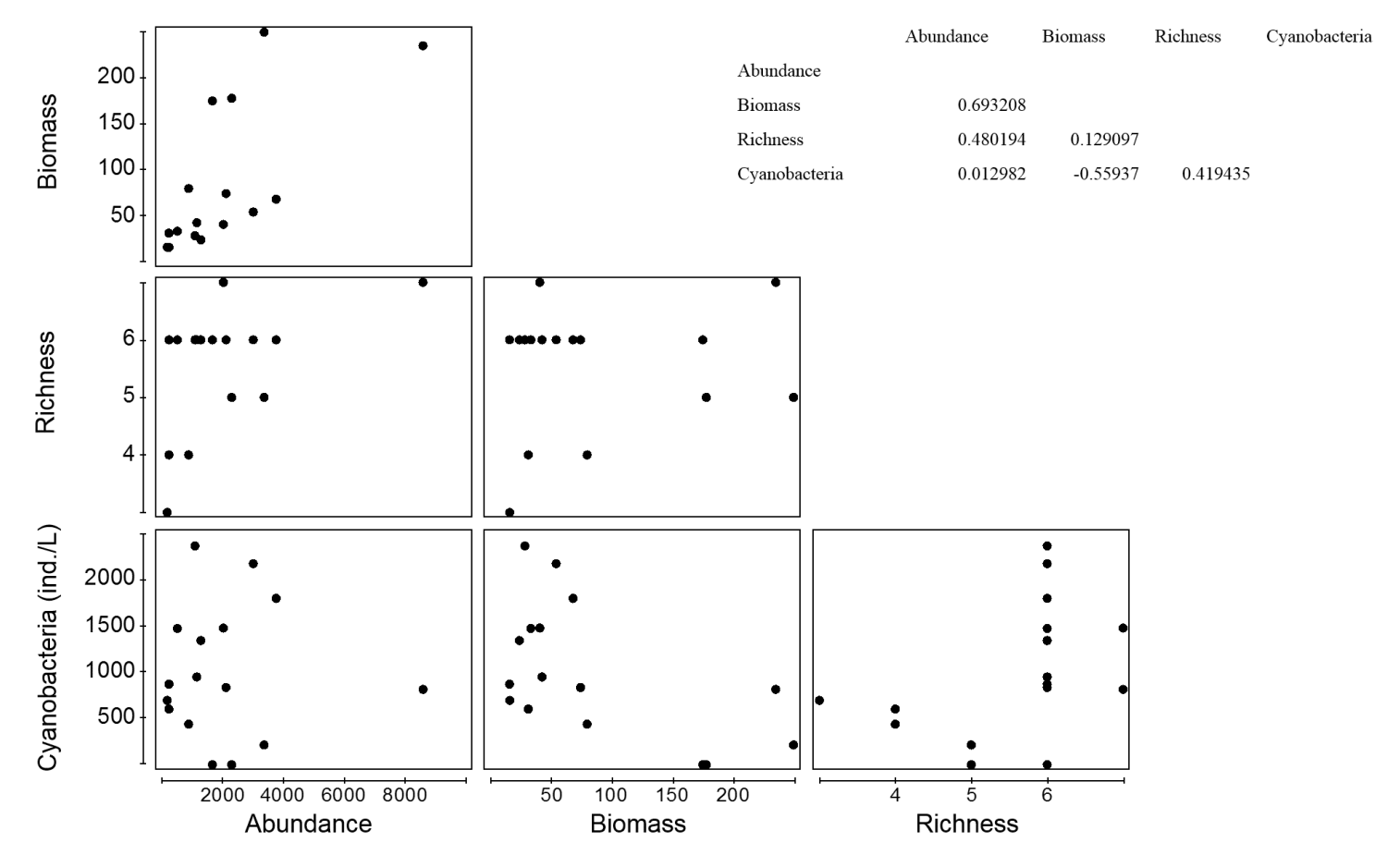

Figure 2. Series of bivariate correlations (Draftsman plot). Spatial representation of the distribution of structural attributes (abundance, biomass and richness) of rotifers in relation to density of Cyanobacteria in the Poçóes Reservoir, Paraíba River basin, State of Paraíba, Brazil. On the right side, data of the series of bivariate correlation.

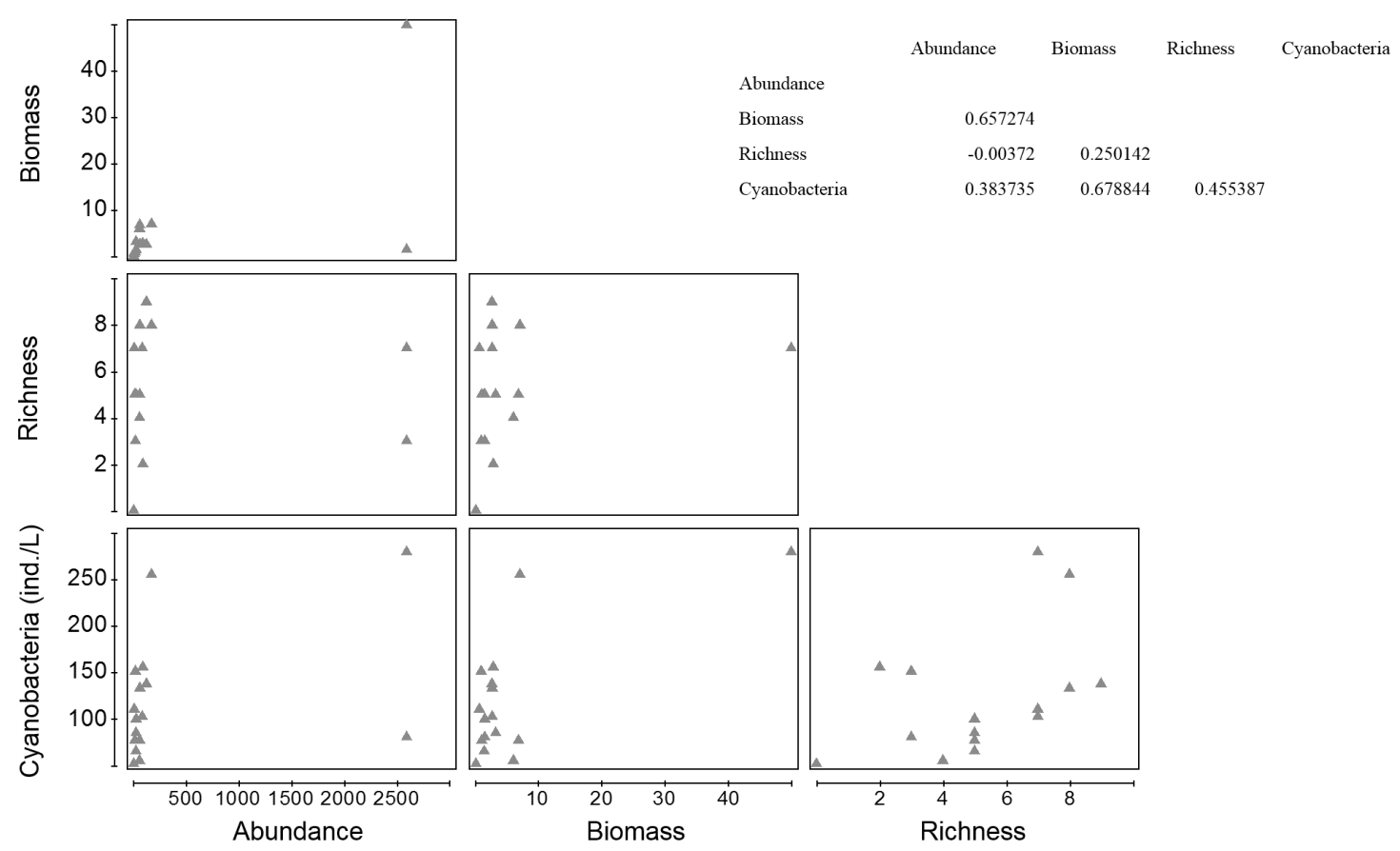

Figura 3. Series of bivariate correlations (Draftsman plot). Spatial representation of the distribution of structural attributes (abundance, biomass and richness) of rotifers in relation to density of Cyanobacteria in the Camalaú Reservoir, Paraíba River basin, State of Paraíba, Brazil. On the right side, data of the series of bivariate correlation.

\section{Discussion}

The results show that the density of cyanobacteria has a positive influence on the structural characteristics of the community of rotifers, except for biomass in the Poçoes reservoir, which seems to be negatively influenced by these organisms. The positive relationship of cyanobacteria has already been observed, even 
守

亶

3

올ำ

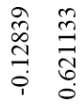

$\frac{\pi}{\stackrel{1}{J}}$

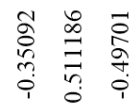

虽

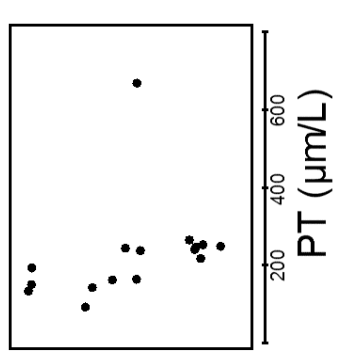

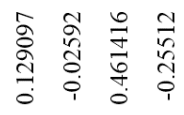

ติ

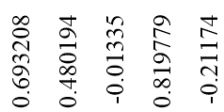

若

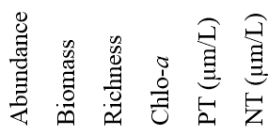

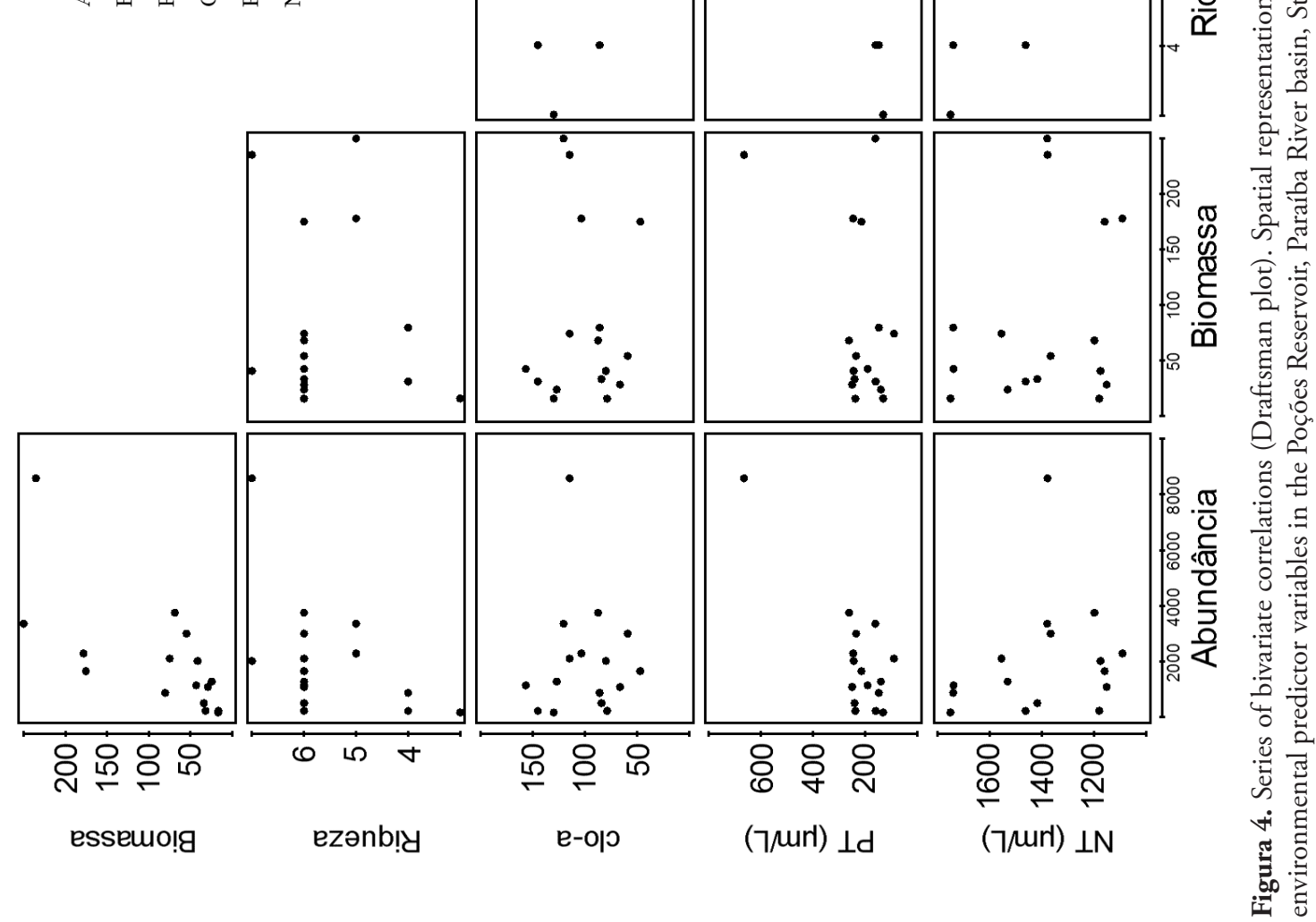


章

$\frac{\infty}{\infty}$

욜ำ

嘀

.

$\begin{array}{ll}\infty & 0 \\ 0 & 0 \\ 0 & 0 \\ 0 & 0 \\ 1 & 0 \\ 1 & 0 \\ 1 & 0\end{array}$

㼂

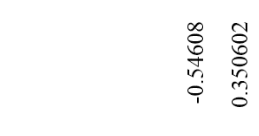

ฉ

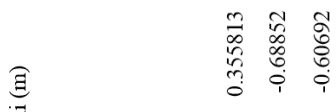

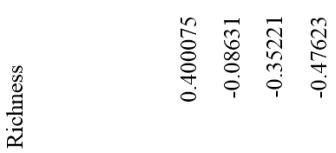

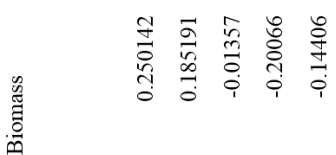

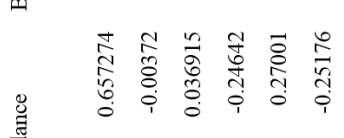

蕓

完

III
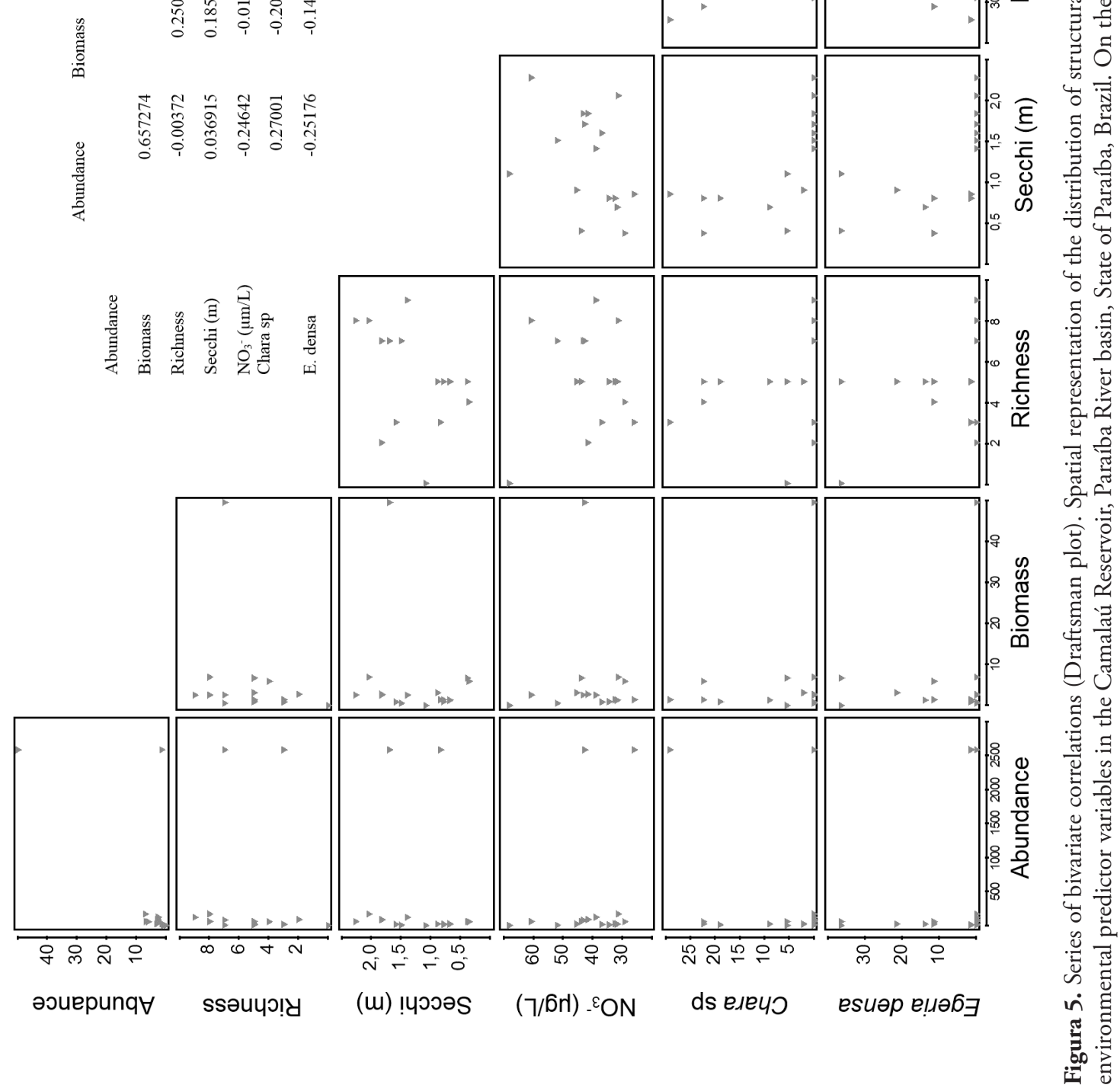
for the zooplankton community as a whole. The high abundance of the assemblages of rotifers in eutrophic ecosystems may be associated to the fact that the rotifers possess wide trophic plasticity (Xi et al., 2002), and although they preferentially utilize the phytoplankton Chlorophyta species as preferential resources, common in oligo- and mesotrophic environments, they are also perfectly able of growing and reproducing when they feed on Cyanobacteria, which are frequent in eutrophic ecosystems (Xi et al., 2002; Claps et al., 2011) or can feed on detritus and bacterioplankton (Bonecker \& Aoyagui, 2005). This negative relationship with biomass, in the Poçóes reservoir, also corroborates with the analysis of the influence of the chlorophyll- $a$ concentrations on structural attributes, in addition to confirming the dominance of these algae in these reservoir.

In the studied reservoirs, the high densities of cyanobacteria suggest the replacement of edible phytoplankton species by filamentous species, which are less palatable; as observed by Wolfinbarger (1999) in lakes in eutrophication, there is a reduction in the richness and abundance of grazing species and records of high numerical rates of rotifers (Havens, 2002), a fact that can also be related to the composition of the zooplankton community in both reservoirs. The decrease in the richness of other groups of zooplankton is possibly explained due to interference on the filtration apparatus of grazing species (Gliwicz \& Lampert, 1990), and the release of substances that inhibit growth and low nutritional value, with the consequent dominance of filter-feeding species such as rotifers (De Bernardi \& Giussani, 1990; Panosso et al., 2003).

In this way, the increased density of cyanobacteria, common in eutrophic aquatic ecosystems, has substantial effects on the ecological dynamics of these ecosystems. This begins with the zooplankton community, which has its composition changed, especially by the reduction in the diversity, and the consequent dominance of opportunistic species, such as rotifers, which are usually the most abundant group in eutrophic environments (Bonecker \& Lansac-Tôha, 1996; Attayde \& Bozelli, 1998; Sousa et al., 2008), as corroborated in the present study. Moreover, this dominance of cyanobacteria can affect the community structure at various levels, since grazing species have an important role in controlling algal growth and can be considered a factor in maintaining the clear status in aquatic environments (Scheffer et al., 1993).
The frequent eutrophic status in Brazilian semiarid reservoirs is an important selective factor for both the structure of rotifers and the composition of the primary producers. These reservoirs are usually shallow and turbid, which is also a selection factor on the biota, favoring the dominance and coexistence of species tolerant to these conditions (Bouvy et al., 1999; EskinaziSant'Anna et al., 2013), which confirms the pattern observed in the present study.

The correlation analysis suggests that environmental factors have a stronger effect in determining the distribution of structural attributes of rotifers than the density of cyanobacteria. Abiotic variables are often reported as determinants for the structure of a zooplankton community. Studies by Attayde \& Bozelli (1998) and Sousa et al. (2008) in aquatic ecosystems in the semiarid region also emphasize that the community distribution in these environments is directly related to trophic conditions.

According to Thornton \& Rast (1993), in the trophic classification criterion for semiarid aquatic ecosystems, Chlo- $a$ concentrations above $60 \mu \mathrm{g} / \mathrm{L}$ and phosphorus concentrations above $12 \mu \mathrm{g} / \mathrm{L}$ characterize eutrophic conditions. In the present work, the Poçôes Reservoir was classified as eutrophic and, in the same reservoir, among the environmental variables, the total phosphorus exerted the greatest influence on the distribution of abundance, richness and biomass of rotifers. Furthermore, this trophic pattern observed may be corroborated by the structure pattern of rotifers in the reservoirs and by the density of cyanobacteria.

At the sites with stands of submerged macrophytes, such as Camalaú Reservoir, there was a positive correlation between rotifer abundance and biomass of Chara sp. Areas with macrophytes, which are recognized as areas for maintaining biodiversity by sustaining higher richness and diversity of communities at several trophic levels compared to homogeneous areas (Attrill et al., 2000; Kostylev et al., 2005; Gomes et al., 2012).

Nevertheless, negative correlations were also found for the other attributes with both Chara sp. and E. densa, which may be related to the fact that the microhabitats provided by the macrophytes also favor zooplankton predator species, macroinvertebrates for example, considering that these areas provide effective niches, allowing the coexistence of species, and reducing the partitioning of resources and subsequent competition (Pianka, 
1988; Bell et al., 1991; Downes et al., 2000; Taniguchi et al., 2003; Burlakova et al., 2012).

Given the above, the main contributions of this study are associated with the fact that the structure of rotifers is related to the density of cyanobacteria, unlike abiotic factors that influence the distribution of structural attributes of rotifers, corroborating our hypothesis.

Besides that, in aquatic bodies with the dominance of cyanobacteria, there is reduced abundance and diversity of grazing species, and the dominance of some rotifer species, due to the biological and physiological characteristics of rotifers that favor this coexistence.

From our data set, it is believed that the population of rotifers is more clearly related to environmental conditions, especially those indicative of trophic conditions, and thus the structural indicator of this population can be used as analysis factors for local environmental conditions. Future studies are suggested in ecosystems containing dominance of rotifers, in order to identify whether the patterns observed in this study also occur in other aquatic ecosystems in the semiarid region.

\section{Acknowledgements}

The authors would like to thank PROPESQ/ UEPB for the research funding and CAPES for the grant of a Masters scholarship to the first author. Thanks also go to the colleagues at the Laboratorio de Ecologia Aquática-UEPB for their support in the field collections.

\section{References}

AGÊNCIA EXECUTIVA DE GESTÃO DAS ÁGUAS DO ESTADO DA PARAÍBA - AESA. Comitê do Rio Paraiba [online]. 2013. [viewed 17 July 2013]. Available from: www.aesa.pb.gov.br

AMERICAN PUBLIC HEALTH ASSOCIATION - APHA, AMERICAN WATER WORKS ASSOCIATION - AWWA and WATER ENVIRONMENT FEDERATION - WEF. Standard methods for the examination of waster and waster-water. 18th ed. New York: APHA/AWWA/ WEF, 1992, pp. 1193.

AN, X.P., DU, Z.H., ZHANG, J.H., LI, Y.P. and QI, J.W. Structure of the zooplankton community in Hulun Lake, China. Procedia Environmental Sciences, 2012, 13, 1099-1109. http://dx.doi.org/10.1016/j. proenv.2012.01.103.

ANAGNOSTIDIS, K. and KOMÁREK, J. Modern approach to the classification system of cyanophytes
3 - oscillatoriales. Algological Studies, 1988, 50-53, 327-472.

ANDERSON, M.J. A new method for non-parametric multivariate analysis of variance. Austral Ecology, 2001a, 26, 32-46.

ANDERSON, M.J. and TER BRAAK, C.T. Permutation tests for multi-factorial analysis of variance. Journal of Statistical Computation and Simulation, 2003, 73(2), 85-113. http://dx.doi. org/10.1080/00949650215733.

ANDERSON, M.J. Permutation tests for univariate or multivariate analysis of variance and regression. Canadian Journal of Fisheries and Aquatic Sciences, 2001b, 58(3), 626-639. http://dx.doi.org/10.1139/ f01-004.

ANDERSON, M.J., GORLEY, R.N. and CLARKE, K.R. PERMANOVA + for PRIMER: guide to software and statistical methods. Plymouth, UK: Primer-e, 2008, $214 \mathrm{p}$.

ANNOR, F.O., VAN DE GIESEN, N., LIEBE, J., VAN DE ZAAG, P., TILMANT, A. and ODAI, S.N. Delineation of small reservoirs using radar imagery in a semi-arid environment: A case study in the upper east region of Ghana. Physics and Chemistry of the Earth, 2009, 34(4-5), 309-315. http://dx.doi. org/10.1016/j.pce.2008.08.005.

ARORA, J. and MEHRA, N.K. Seasonal dynamics of rotifers in relation to physical and chemical conditions of the river Yamuna (Delhi), India. Hydrobiologia, 2003, 491(1-3), 101-109. http:// dx.doi.org/10.1023/A:1024490805310.

ATTAYDE, J.L. and BOZELLI, R.L. Assessing the indicator properties of zooplankton assemblages to disturbance gradients by canonical correspondence analysis. Canadian Journal of Fisheries and Aquatic Sciences, 1998, 55(8), 1789-1797. http://dx.doi. org/10.1139/f98-033.

ATTRILL, M.J., STRONG, J.A. and ROWDEN, A.A. Are macroinvertebrate communities influenced by seagrass structural complexity? Ecography, 2000, 23(1), 114-121. http://dx.doi. org/10.1111/j.1600-0587.2000.tb00266.x.

BADSI, H., ALI, H.O., LOUDIKI, M., EL HAFA, M., CHAKLI, R. and AAMIRI, A. Ecological factors affecting the distribution of zooplankton community in the Massa Lagoon (Southern Morocco). African Journal of Environmental Science and Technology, 2010, 4(11), 751-762.

BELL, S.S., MCCOY, E.D. and MUSHINSKY, H.R., eds Habitat Structure: the physical arrangement of objects in space. London: Chapman and Hall, 1991. http://dx.doi.org/10.1007/978-94-011-3076-9.

BENNDORF, J. Possibilities and limits for controlling eutrophication by biomanipulation. Internationale Revue der Gesamten Hydrobiologie und Hydrographie, 
1995, 80(4), 519-534. http://dx.doi.org/10.1002/ iroh. 19950800404.

BICUDO, C.E.M. and MENEZES, M., orgs. Gêneros de algas de águas continentais. 2nd ed. São Carlos: Rima, 2006, pp. 489.

BIELAŃSKA-GRAJNER, I. and GŁADYSZ, A. Planktonic rotifers in mining lakes in the Silesian Upland: Relationship to environmental parameters. Limnologica - Ecology and Management of Inland Waters, 2010, 40(1), 67-72. http://dx.doi. org/10.1016/j.limno.2009.05.003.

BLINDOW, I., HARGEBY, A., MEYERCORDT, J. and SCHUBERT, H. Primary production in two shallow lakes with contrasting plant form dominance: A paradox of enrichment? Limnology and Oceanography, 2006, 51(6), 2711-2721. http:// dx.doi.org/10.4319/lo.2006.51.6.2711.

BONECKER, C.C. and AOYAGUI, A.S.M. Relationships between rotifers, phytoplankton and bacterioplankton in the Corumbá reservoir, Goiás State, Brazil. Hydrobiologia, 2005, 546(1), 415-421. http://dx.doi.org/10.1007/s10750-005-4284-1.

BONECKER, C.C. and LANSAC-TÔHA, F.A. Community structure of rotifers in two environments of the upper River Paraná floodplain (MS) - Brazil. Hydrobiologia, 1996, 325(2), 137-150. http://dx.doi. org/10.1007/BF00028274.

BONILLA, S., AUBRIOT, L., SOARES, M.C.S., GONZÁLEZ-PIANA, M., FABRE, A., HUSZAR, V.L., LÜRLING, M., ANTONIADES, D., PADISÁK, J. and KRUK, C. What drives the distribution of the bloom-forming cyanobacteria Planktothrix agardhii and Cylindrospermopsis raciborskii? FEMS Microbiology Ecology, 2012, 79(3), 594-607. http://dx.doi.org/10.1111/j.15746941.2011.01242.x. PMid:22092489

BOUVY, M., MOLICA, R., DE OLIVEIRA, S., MARINHO, M. and BEKER, B. Dynamics of a toxic cyanobacterial bloom (Cylindrospermopsis raciborskii) in a shallow reservoir in the semi-arid region of northeast Brazil. Aquatic Microbial Ecology, 1999, 20(3), 285-297. http://dx.doi.org/10.3354/ ame020285.

BRAINWOOD, M. and BURGIN, S. Hotspots of biodiversity or homogeneous landscapes? Farm dams as biodiversity reserves in Australia. Biodiversity and Conservation, 2009, 18(11), 3043-3052. http:// dx.doi.org/10.1007/s10531-009-9623-5.

BUNN, S.E. and ARTHINGTON, A.H. Basic principles and ecological consequences of altered flow regimes for aquatic biodiversity. Environmental Management, 2002, 30(4), 492-507. http://dx.doi. org/10.1007/s00267-002-2737-0. PMid:12481916

BURLAKOVA, L.E., KARATAYEV, A.Y. and KARATAYEV, V.A. Invasive mussels induce community changes by increasing habitat complexity.
Hydrobiologia, 2012, 685(1), 121-134. http://dx.doi. org/10.1007/s10750-011-0791-4.

CHELLAPPA, S., BUENO, R.M., CHELLAPPA, T., CHELLAPPA, N.T., ALMEIDA, E. and VAL, V.M.F. Reproductive seasonality of the fish fauna and limnoecology of semi-arid Brazilian reservoirs. Limnologica - Ecology and Management of Inland Waters, 2009, 39(4), 325-329.

CHEN, W., LIU, L., ZHANG, Q. and DAI, S. Effects of nitrite and toxic Microcystis aeruginosa PCC7806 on the growth of freshwater rotifer Brachionus calyciflorus. Bulletin of Environmental Contamination and Toxicology, 2011, 86(3), 263-267. PMid:21290099

CHESTER, E.T. and ROBSON, B.J. Anthropogenic refuges for freshwater biodiversity: Their ecological characteristics and management. Biological Conservation, 2013, 166, 64-75. http://dx.doi. org/10.1016/j.biocon.2013.06.016.

CLAPS, M.C., GABELLONE, N.A. and BENÍTEZ, H.H. Seasonal changes in the vertical distribution of rotifers in a eutrophic shallow lake with contrasting states of clear and turbid water. Zoological Studies, 2011, 50, 454-465.

CLARKE, K.R. and AINSWORTH, M. A method of linking multivariate community structure to environmental variables. Marine Ecology Progress Series, 1993, 92, 205-219. http://dx.doi.org/10.3354/ meps092205.

COLE, G.A. Textbook of limnology. 4th ed. Long Grove: Waveland Press, 1994, 412 p.

DANTAS, E.W., MOURA, A.N., BITTENCOURTOLIVEIRA, M.C., ARRUDA NETO, J.D.T. and CAVALCANTI, A.D.C. Temporal variation of the phytoplankton community at short sampling intervals in the Mundau reservoir, Northeastern Brazil. Acta Botanica Brasilica, 2008, 22(4), 970-982. http:// dx.doi.org/10.1590/S0102-33062008000400008.

DE BERNARDI, R. and GIUSSANI, G. Are blue-green algae a suitable food for zooplankton? An overview. Hydrobiologia, 1990, 200-201(1), 29-41. http:// dx.doi.org/10.1007/BF02530326.

DOWNES, B.J., LAKE, P.S., SCHREIBER, E.S.G. and GLAISTER, A. Habitat structure, resources and diversity: the separate effects of surface roughness and macroalgae on stream invertebrates. Oecologia, 2000, 123(4), 569-581. http://dx.doi.org/10.1007/ PL00008862.

DUFFY, J.E., CARDINALE, B.J., FRANCE, K.E., MCINTYRE, P.B., THÉBAULT, E. and LOREAU, $M$. The functional role of biodiversity in ecosystems: incorporating trophic complexity. Ecology Letters, 2007, 10(6), 522-538. PMid:17498151

ESKINAZI-SANT'ANNA, E.M., MENEZES, R., COSTA, I.S., ARAÚJO, M., PANOSSO, R. and ATTAYDE, J.L., and the ESKINAZI-SANT'ANNA 
Zooplankton assemblages in eutrophic reservoirs of the Brazilian semi-arid. Brazilian Journal of Biology, 2013, 73(1), 37-52. http://dx.doi.org/10.1590/ S1519-69842013000100006. PMid:23644787

ESKINAZI-SANT'ANNA, E.M., MENEZES, R., COSTA, I.S., PANOSSO, R.F., ARAÚJO, M.F. and ATTAYDE, J.L. Composição da comunidade zooplanctônica em reservatórios eutróficos do semiárido do Rio Grande do Norte. Oecologia Brasiliensis, 2007, 11(3), 410-421. http://dx.doi.org/10.4257/ oeco.2007.1103.10.

FANNY, C., VIRGINIE, A., JEAN-FRANÇOIS, F., JONATHAN, B., MARIE-CLAUDE, R. and SIMON, D. Benthic indicators of sediment quality associated with run-of-river reservoirs. Hydrobiologia, 2013, 703(1), 149-164. http://dx.doi.org/10.1007/ s10750-012-1355-y.

GENG, H., XIE, P., DENG, D. and ZHOU, Q. The rotifer assemblage in a shallow, eutrophic Chinese lake and its relationships with cyanobacterial blooms and crustacean zooplankton. Journal of Freshwater Ecology, 2005, 20(1), 93-100. http://dx.doi.org/10. 1080/02705060.2005.9664941.

GLIWICZ, Z.M. and LAMPERT, W. Food thresholds in Daphnia species in the absence and presence of blue-green filaments. Ecology, 1990, 71(2), 691-702. http://dx.doi.org/10.2307/1940323.

GOMES, L.C., BULLA, C.K., AGOSTINHO, A.A., VASCONCELOS, L.P. and MIRANDA, L.E. Fish assemblage dynamics in a Neotropical floodplain relative to aquatic macrophytes and the homogenizing effect of a flood pulse. Hydrobiologia, 2012, 685(1), 97-107. http://dx.doi.org/10.1007/ s10750-011-0870-6.

HAVENS, K.E. Cyanobacteria blooms: effects on aquatic ecosystems. In H.K. Hudnell, ed. Cyanobacterial harmful algal blooms: state of the science and research needs. New York: Springer, 2008, pp. 733-747. http:// dx.doi.org/10.1007/978-0-387-75865-7_33.

HAVENS, K.E. Zooplankton structure and potential food web interactions in the plankton of a subtropical chain-of-lakes. TheScientific WorldJournal, 2002, 2, 926-942. http://dx.doi.org/10.1100/tsw.2002.171. PMid:12805947

KOKO CIŃSKI， M. , S TEFANIAK, K., MANKIEWICZ-BOCZEK, J., IZYDORCZYK, $\mathrm{K}$. and SOININEN, J. The ecology of the invasive cyanobacterium Cylindrospermopsis raciborskii (Nostocales, Cyanophyta) in two hypereutrophic lakes dominated by Planktothrix agardhii (Oscillatoriales, Cyanophyta). European Journal of Phycology, 2010, 45(4), 365-374. http://dx.doi.org/10.1080/096702 62.2010 .492916$.

KOMÁREK, J. and ANAGNOSTIDIS, K. Modern approach to the classification system of cyanophytes 4 - nostocales. Algological Studies, 1989, 82, 247-345.
KÖPPEN, W. Das geographisce System der Klimate. Berlin: Verlag von Gebrüder Borntraeger, 1936, pp. 1-44.

KOSTE, W. Rotatoria: Die Rädertiere Mitteleroupas Ein Bestimmungswerk begründet von Max Voigt. Uberordnung Monogonta. 2nd ed. Berlin: Gebrüder Borntraeger, 1978, pp. 637.

KOSTYLEV, V.E., ERLANDSSON, J., MING, M.Y. and WILLIAMS, G.A. The relative importance of habitat complexity and surface area in assessing biodiversity: fractal application on rocky shores. Ecological Complexity, 2005, 2(3), 272-286. http:// dx.doi.org/10.1016/j.ecocom.2005.04.002.

LORENZEN, C.J. Determination of chlorophyll and pheo-pigments: spectrophotometric equations. Limnology and Oceanography, 1967, 12(2), 343-346. http://dx.doi.org/10.4319/lo.1967.12.2.0343.

LUND, J.W.G., KIPLING, C. and LECREN, E.D. The invert microscope method of estimating algal numbers and the statistical basis of estimations by counting. Hydrobiologia, 1958, 11(2), 143-170. http://dx.doi.org/10.1007/BF00007865.

MALEKZADEH VIAYEH, R. and ŠPOLJAR, M. Structure of rotifer assemblages in shallow waterbodies of semi-arid northwest Iran differing in salinity and vegetation cover. Hydrobiologia, 2012, 686(1), 73-89. http://dx.doi.org/10.1007/s10750011-0992-x.

MARGALEF, R.M. Distribución de los macrofitos de las aguas dulces y salobres del E. y NE de España y dependencia de la composión quimica del medio. Madrid: Fundación Juan March, 1981.

MCGREGOR, G.B. and FABBRO, L.D. Dominance of Cylindrospermopsis raciborskii (Nostocales, Cyanoprokaryota) in Queensland tropical and subtropical reservoirs: Implications for monitoring and management. Lakes and Reservoirs: Research and Management, 2000, 5(3), 195-205. http://dx.doi. org/10.1046/j.1440-1770.2000.00115.x.

MEDINA-GÓMEZ, I. and HERRERA-SILVEIRA, J.A. Primary production dynamics in a pristine groundwater influenced coastal lagoon of the Yucatan Peninsula. Continental Shelf Research, 2006, 26(8), 971-986.

MORENO, P., FRANÇA, J.S., FERREIRA, W.R., PAZ, A.D., MONTEIRO, I.M. and CALLISTO, M. Use of the BEAST model for biomonitoring water quality in a neotropical basin. Hydrobiologia, 2009, 630(1), 231-242. http://dx.doi.org/10.1007/ s10750-009-9796-7.

MOURA, A.D.N., BITTENCOURT-OLIVEIRA, M.D.C., DANTAS, Ê.W. and ARRUDA NETO, J.D.D.T. Phytoplanktonic associations: a tool to understanding dominance events in a tropical Brazilian reservoir. Acta Botanica Brasilica, 2007, 21(3), 641-648. http://dx.doi.org/10.1590/S010233062007000300011. 
MOURA, A.N., DANTAS, E.W., OLIVEIRA, H.S.B. and BITTENCOURT-OLIVEIRA, M.C. Vertical and temporal dynamics of cyanobacteria in the Carpina potable water reservoir in northeastern Brazil. Brazilian Journal of Biology, 2011, 71(2), 451-459. http://dx.doi.org/10.1590/S151969842011000300015. PMid:21755163

PACE, M.L. and ORCUTT, J.D.J.R. The relative importance of protozoans, rotifers and crustaceans in a freshwater zooplankton community. Limnology and Oceanography, 1981, 26(5), 822-830. http://dx.doi. org/10.4319/lo.1981.26.5.0822.

PANOSSO, R., CARLSSON, P., KOZLOWSKYSUZUKI, B., AZEVEDO, S.M. and GRANÉLI, E. Effect of grazing by a neotropical copepod, Notodiaptomus, on a natural cyanobacterial assemblage and on toxic and non-toxic cyanobacterial strains. Journal of Plankton Research, 2003, 25(9), 1169-1175. http://dx.doi.org/10.1093/ plankt/25.9.1169.

PERETYATKO, A., TEISSIER, S., DE BACKER, S. and TRIEST, L. Restoration potential of biomanipulation for eutrophic peri-urban ponds: the role of zooplankton size and submerged macrophyte cover. Hydrobiologia, 2009, 634(1), 125-135. http:// dx.doi.org/10.1007/s10750-009-9888-4.

PIANKA, E.R. Evolutionary ecology. New York: Harper and Row, 1988.

PINTO-COELHO, R.M. Métodos de coleta, preservação, contagem e determinação da biomassa em zooplâncton de águas epicontinentais. In E.M. Bicudo and D.C. Bicudo, eds. Amostragem em limnologia. São Carlos: RiMa: 2004, pp. 149-165.

REVENGA, C., CAMPBELL, I., ABELL, R., DE VILLIERS, P. and BRYER, M. Prospects for monitoring freshwater ecosystems towards the 2010 targets. Philosophical Transactions of the Royal Society of London. Series B, Biological Sciences, 2005, 360(1454), 397-413. http://dx.doi.org/10.1098/rstb.2004.1595. PMid:15814353

ROSS, J. Prácticas de ecología. Barcelona: Ediciones Omega, 1979, $181 \mathrm{p}$.

RUTTNER-KOLISKO, A. Plankton rotifers: biology and taxonomy (Monogononta). Buchhandlung Stuttgart: Schweizerbart'sche verlags, 1974, pp. 1-146.

RUTTNER-KOLISKO, A. Suggestions for biomass calculations of plankton rotifers. Archiv für Hydrobiologie. Beihefte. Ergebnisse der Limnologie, 1977, 8, 71-76.

SANT'ANNA, C.L., AZEVEDO, M.T.P., AGUJARO, L.F., CARVALHO, M.C., CARVALHO, L.R. and SOUZA, R.C.R. Manual ilustrado para identificação e contagem de cianobactérias planctônicas de águas continentais brasileiras. São Paulo: Interciencia, 2006, pp. 58.

SCHEFFER, M., HOSPER, S.H., MEIJER, M.L., MOSS, B. and JEPPESEN, E. Alternative equilibria in shallow lakes. Trends in Ecology \& Evolution, 1993, 8(8), 275-279. http://dx.doi.org/10.1016/01695347(93)90254-M. PMid:21236168

SEREDIAK, N.A., PREPAS, E.E. and PUTZ, G.J. Eutrophication of Freshwater Systems. Environmental Geochemistry, 2014, 11, 305-323.

SOUSA, W., ATTAYDE, J.L., ROCHA, E.D.S. and ESKINAZI-SANT'ANNA, E.M. The response of zooplankton assemblages to variations in the water quality of four man-made lakes in semi-arid northeastern Brazil. Journal of Plankton Research, 2008, 30(6), 699-708. http://dx.doi.org/10.1093/ plankt/fbn032.

TANIGUCHI, H., NAKANO, S. and TOKESHI, M. Influences of habitat complexity on the diversity and abundance of epiphytic invertebrates on plants. Freshwater Biology, 2003, 48(4), 718-728. http:// dx.doi.org/10.1046/j.1365-2427.2003.01047.x.

THORNTON, J.A. and RAST, W. A test of hypotheses relating to the comparative limnology and assessment of eutrophication in semi-arid man-made lakes. In Y. STRASKRABA, J.G. TUNDISI and A. DUNCAN, eds. Comparative reservoir limnologyand water quality management. London: Kluwer Academic Publishers, 1993, pp. 1-24.

TIXIER, G., LAFONT, M., GRAPENTINE, L., ROCHFORT, Q. and MARSALEK, J. Ecological risk assessment of urban stormwater ponds: Literature review and proposal of a new conceptual approach providing ecological quality goals and the associated bioassessment tools. Ecological Indicators, 2011, 11(6), 1497-1506. http://dx.doi.org/10.1016/j. ecolind.2011.03.027.

TUNDISI, J.G. Reservatórios como sistemas complexos: teoria, aplicaçóes e perspectivas para usos múltiplos. In R. Henry, ed. Ecologia de reservatórios: estrutura, função e aspectos sociais. São Paulo: FUNDIBIO/ FAPESP, 1999, pp. 19-38.

UHELINGER, V. Étude statisque des méthodes de dénobrement planctonique. Archives des Sciences, 1964, 17, 121-123.

UTERMÖHL, H. Zur Vervollkommnung der quantitativen Phytoplankton-Methodik. Mitt. Internationale Ver. Theoretische und Angewandte Limnologie, 1958, 9, 1-38.

VASCONCELOS, J.F., BARBOSA, J.E.L., DINIZ, C.R. and CEBALLOS, B.S.O. Cianobactérias em reservatórios do Estado da Paraíba: ocorrência, toxicidade e fatores reguladores. Boletim da Sociedade Brasileira de Limnologia, 2011, 39(2), 1-20.

VASCONCELOS, J.F., BARBOSA, J.E.L., LIRA, W. and AZEVEDO, S.M.F.O. Microcystin bioaccumulation can cause a potential mutagenic effects in farm fish. Egyptian Journal of Aquatic Research, 2013, 60, 1-9.

WANG, S., XIE, P. and GENG, H. The relative importance of physicochemical factors and crustacean zooplankton as determinants of rotifer density and 
species distribution in lakes adjacent to the Yangtze River, China. Limnologica - Ecology and Management of Inland Waters, 2010, 40(1), 1-7. http://dx.doi. org/10.1016/j.limno.2009.03.001.

WEN, X.L., XI, Y.L., QIAN, F.P., ZHANG, G. and XIANG, X.L. Comparative analysis of rotifer community structure in five subtropical shallow lakes in East China: role of physical and chemical conditions. Hydrobiologia, 2011, 661(1), 303-316. http://dx.doi.org/10.1007/s10750-010-0539-6.

WOLFINBARGER, W.C. Influences of biotic and abiotic factors on seasonal succession of zooplankton in Hugo Reservoir, Oklahoma, USA. Hydrobiologia, 1999, 400, 13-31. http://dx.doi. org/10.1023/A:1003738608697.
XI, Y.L., LIU, G.Y. and JIN, H.J. Population growth, body size, and egg size of two different strains of Brachionus calyciflorus Pallas (Rotifera) fed different algae. Journal of Freshwater Ecology, 2002, 17(2), 185-190. http://dx.doi.org/10.1080/02705060.20 02.9663886.

ZHAO, J., RAMIN, M., CHENG, V. and ARHONDITSIS, G.B. Plankton community patterns across a trophic gradient: the role of zooplankton functional groups. Ecological Modelling, 2008, 213(3-4), 417-436. http://dx.doi. org/10.1016/j.ecolmodel.2008.01.016.

Received: 21 February 2014 Accepted: 15 December 2014 